\title{
Extracting Four Solar Model Electrical Parameters of Mono-Crystalline Silicon (mc-Si) and Thin Film (CIGS) Solar Modules using Different Methods
}

\author{
Narjes Sadeq Katee \\ M.Sc. Student \\ Department of Energy Engineering \\ College of Engineering \\ University of Baghdad \\ Iraq-Baghdad \\ snarjes565@gmail.com
}

\author{
Oday Ibraheem Abdullah \\ Assist. Prof Dr. \\ Department of Energy Engineering \\ College of Engineering \\ University of Baghdad \\ Iraq-Baghdad \\ odayia2007@gmail.com
}

\author{
Emad Talib Hashim \\ Assist. Prof Dr. \\ Department of Energy Engineering \\ College of Engineering \\ University of Baghdad \\ Iraq-Baghdad \\ emadchem70@yahoo.com
}

\begin{abstract}
Experimental measurements were done for characterizing current-voltage and power-voltage of two types of photovoltaic (PV) solar modules; monocrystalline silicon ( $m c-S i)$ and copper indium gallium di-selenide (CIGS). The conversion efficiency depends on many factors, such as irradiation and temperature. The assembling measures as a rule cause contrast in electrical boundaries, even in cells of a similar kind. Additionally, if the misfortunes because of cell associations in a module are considered, it is hard to track down two indistinguishable photovoltaic modules. This way, just the I-V, and P-V bends' trial estimation permit knowing the electrical boundaries of a photovoltaic gadget with accuracy. This measure gives extremely significant data to the plan, establishment, and upkeep of PV frameworks. Three methods, simplified explicit, slope, and iterative, are used to compute two solar models' parameters using MATLAB code. The percentage maximum power errors at $\left(600\right.$ and 1000) $\mathrm{W} / \mathrm{m}^{2}$ for both current-voltage and powervoltage values with the corresponding measured ones using the slope method are $0.5 \%$ and $3 \%$ for monocrystalline silicon copper indium gallium di-selenide, respectively. The iterative method is 5 $\%$ and $10 \%$ for monocrystalline silicon and copper indium gallium di-selenide. Finally, for the simplified explicit $8 \%$ and $9 \%$, for monocrystalline silicon and copper indium gallium di-selenide, respectively. The slope method gives more close results with the corresponding measured values than the other two methods for the two PV solar modules used. Consequently, the slope method is less influenced by the meteorological condition.
\end{abstract}

Keywords: solar modules, voltage, current, computing, parameters.

*Corresponding author

Peer review under the responsibility of University of Baghdad.

https://doi.org/10.31026/j.eng.2021.04.02

2520-3339 (C) 2019 University of Baghdad. Production and hosting by Journal of Engineering.

This is an open access article under the CC BY4 license http://creativecommons.org/licenses/by /4.0/).

Article received: $15 / 12 / 2020$

Article accepted: 23/1/2021

Article published:1/4/2021 


\title{
Number $4 \quad$ Volume 27 April $2021 \quad$ Journal of Engineering
}

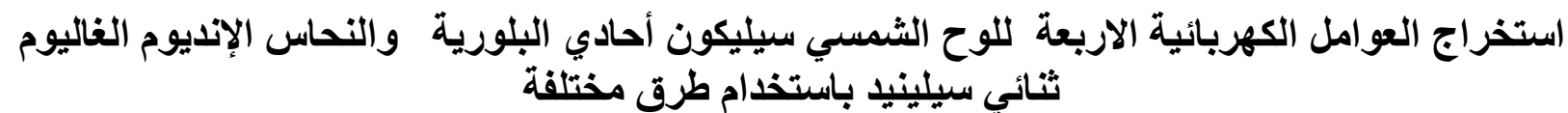

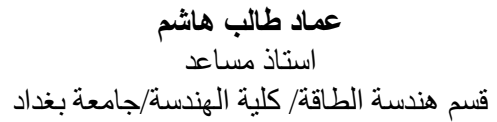

عدي ابراهيم عبلاله

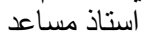

قسم هندسة الطاقة/ كلية الهندسة/جامعة بغداد

نرجس صادق كاطع

طالبة ماجستنر

قسم هندسة الطاقة/ كلية الهندسة/جامعة بغداد

الخلاصة

تم إجر اء قياسات تجريبية لتحديد خصائص I-V, P-V لنو عين من الخلايا الثمسية ( السليكون احادي البلورية والنحاس الانديوم

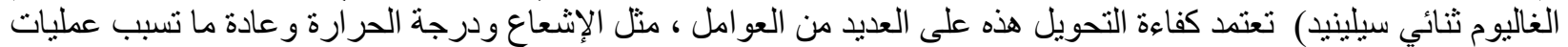

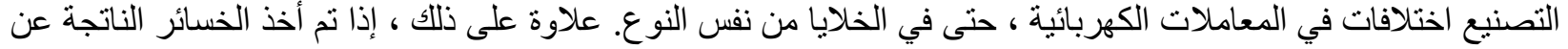

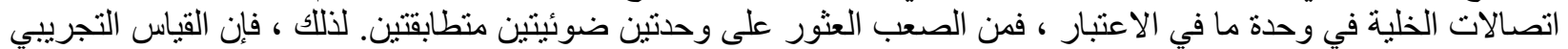

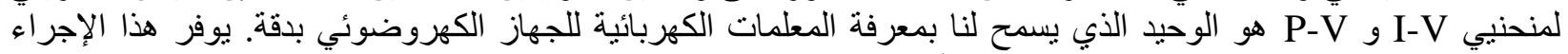

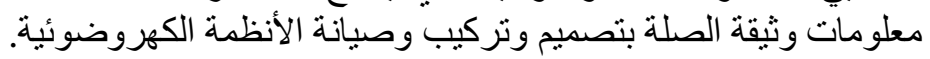
وبذللك ثلاث طرق يتم استخدامها، صريح مبسط و منحدر ومتكررو باستخدام كود الماتلاب للحساب المعلمات الاربعة لنو عين من التهرئ

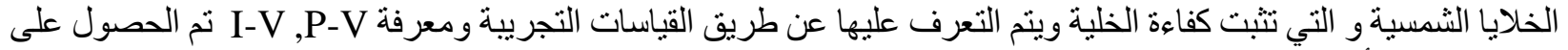

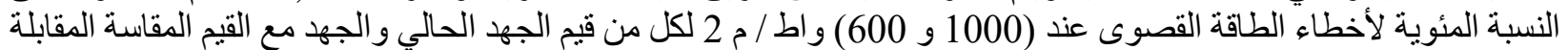

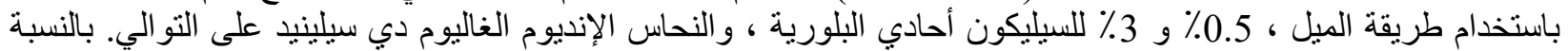

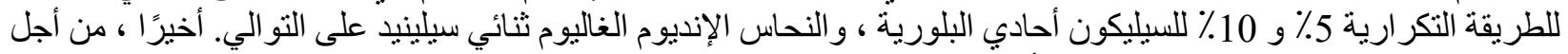

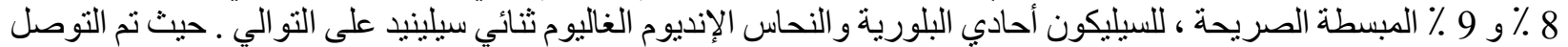

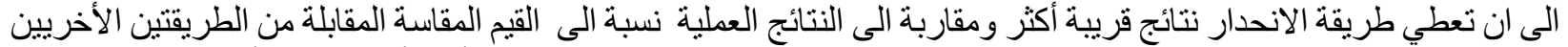

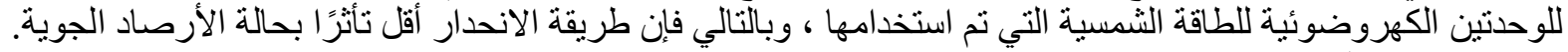

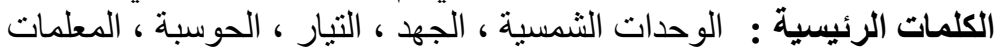

\section{INTRUDUCTION}

Recently, the world is moving towards the use of alternative energy systems. This led to an increase in the utilization of renewable energy where the solar station is one of the most prominent renewable power stations, particularly On-Grid PV solar-type that is the lowest cost among the other types of hybrid and Off-Grid PV solar stations, as well as, the On-Grid need lease maintenance compared with others. (Obaid, et al., 2020). Furthermore, the PV solar system's merits can be connected to nearby loads and do not cause any pollution like what happens in traditional stations (Kumar, et al., 2020). As well as the flexibility to build large-scale PV solar power plants or small systems as needed. Among its benefits, solar systems are easily expanded in spite of their relatively high cost (Necaibia, et al., 2018). The fundamental elements of a PV system equipment are the photovoltaic PV cell that converts sunlight directly into electricity (Ebrahimi, et al., 2019). These cells are arranged in a PV module that incorporate of several pre-wired cells in series (Catelani, et al., 2016). The modules parallel connection led to a current boost while the voltage increases by the modules series connection. These connections assist a powerful PV array constructed by parallel and series connection of modules (Hashim, et al., 2019). The evaluation of the PV modules' performance is normally conducted in the standard test condition (STC). An average solar spectrum at AM 1.5 is used, and $1000 \mathrm{~W} / \mathrm{m}^{2}$ normalized radiance and the cell temperature is a limit of $25^{\circ} \mathrm{C}$ (Cattin, et al., 2019). Temperature effect on the sun-powered module's electric yield boundaries was explored tentatively, and their temperature coefficients were determined. These temperature coefficients are significant for all frameworks plan and estimating (Hashim, et al., and Akram et al., 2016). In any case, under genuine working 
conditions i.e., brilliance variety, just as huge temperature changes, the business modules don't essentially carry on as given makers determinations report (Ali, et al., 2017). Moreover, PV modules perform distinctively as per the area, time, and period of the year (Mathew and Hossain, 2017). Normally, PV sun-based cells conduct portrayed by the same circuit of the single diode model, the 2-diode model, or the 3-diode model (Chaibi, et al., 2019). A few examinations have been led to recognize PV sun-based cell attributes. (Ahmad, et al., 2016) introduced a correlation between the twofold diode model and single-diode model of photovoltaic (PV) module to ascertain the exactness of PV cell for various variable boundaries. From this time forward, the two models were performing Mat lab code by changing the model's boundaries with comparable setups. In any case, (Chen, et al., 2020) proposed a broadening upgraded Harris falcon's improvement (HHO) in light of the disorderly floats roughly the best specialist and a resistance-based exploratory system. This was directed to distinguish obscure boundaries of photovoltaic model modules proficiently. This epic method was utilized to assess sun-powered cell models' boundaries for single diode, twofold diode, and photovoltaic module. (Yu, et al., 2017) recognized the dependably and precisely of the of various PV models boundaries qualities. Advancement JAYA (IJAYA) calculation Improvement was proposed then used to distinguish and tackle the attributes of the boundaries of various PV models, i.e., twofold diode and single diode of the PV module. The correlation of IJAYA with other condition-of-the-state calculations demonstrates that comprehensive test results and insight of IJAYA can get a decent serious exhibition, particularly as far as dependability and exactness. It is important to compute the essential boundaries that control the current-voltage trademark bends (Hahsim et al., 2016). A non-straight current-voltage (I-V) trademark exists in the sun-oriented cell conduct. Different portrayals have been proposed to depict the current-voltage relationship (I-V) in sunlight-based cells (Munji, 2010). Lumped boundary comparable circuit model is regularly used to reproduce its conduct under various working conditions. There are two principle comparable circuit models used to portray the nonlinear I-V relationship: single and twofold diode models. Regardless of what sorts of models, there are significant PV boundaries that should be precisely separated for the recreation, plan, execution assessment, and control of sun-oriented cell frameworks. The principle boundaries that depict sun-oriented cell model conduct are the produced photocurrent, immersion current, arrangement opposition, shunt obstruction, and diode ideality factor. The electrical flow delivered by a sun-oriented cell relies upon the episode light's force and its inherent properties. A precise assessment of the cell boundaries needed for exact execution evaluation (Wolf et al., 1977). The exactness of PV module mostly relies upon the PV module models' exactness and the extraction strategies being utilized to decide the model's boundaries. A few boundary extraction techniques have been proposed lately, and some of the commitments are being evaluated here. These strategies can be classified into three categories such as analytic, iterative, and evolutionary computational methods (Subudhi et al., 2011). The aim of the present work is to compute 4-parameters of a solar model for two types of solar modules (monocrystalline silicon that is classified to the first generation, and caindium gallium di-selenide as the second generation of PV cell ) using three different computing methods; simplified explicit method, slope method, an iterative method, and these methods are simple and close accurate, to the experimental measurements. A new code was built using Matlab to find the solutions of each solar module using any method. Where, based on this new code, it will be very easy to compare between results to find the most optimal method for the calculations. 


\section{PV SOLAR CELL CHARACTERISTICS}

Fig.1 shows the single-diode model that exhibits worthy compromise between accuracy and simplicity, according to numerous authors (Villalva, et al., 2009, Khezzar, 2009, Celik, and Acikgoz, 2007). The model of four-parameter supposes that shunt resistance of infinite value and can obtain from the basic equation of output current of the PV module (Khezzar, 2009):

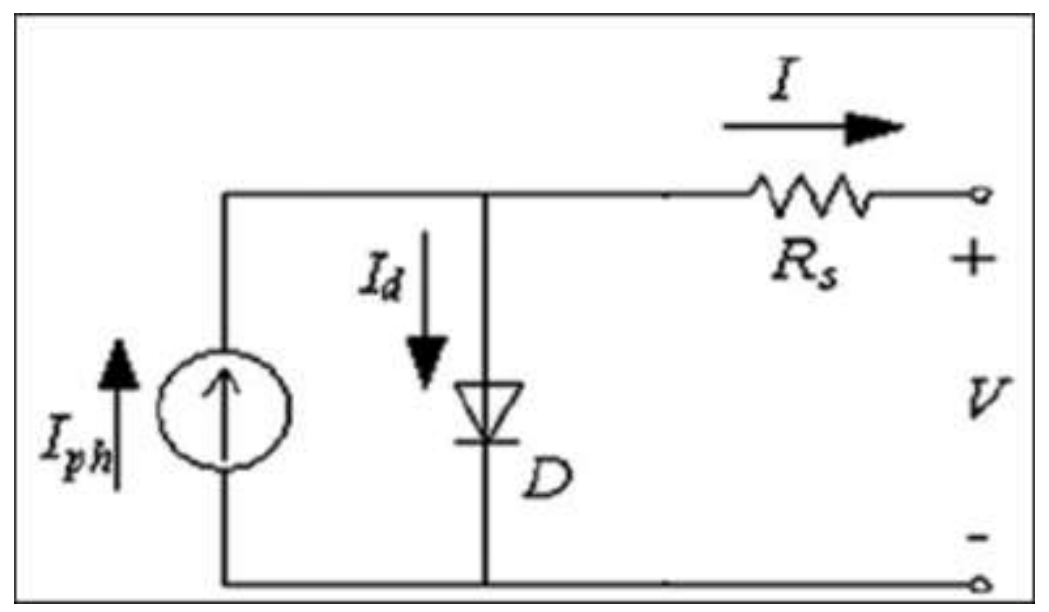

Figure 1. Four parameters model equivalent circuit of a PV solar cell.

$I=I_{p h}-I_{o}\left[\exp \left(\frac{q\left(V+I R_{s}\right)}{N_{s} A k_{B} T}\right)-1\right]$

The manufacturers give three fundamental points on the I-V curve at STC condition of opencircuit voltage, short circuit current, and maximum power point (Khezzar, 2009) therefore, Eq. (1) can be written as:

Short circuit current point $\left(0, \mathrm{I}_{\mathrm{sc}}\right)$ :

$I_{s c}=I_{p h}-I_{o}\left[\exp \left(\frac{q I_{s c} R_{s}}{N_{s} A k_{B} T}\right)-1\right]$

Open circuit voltage point $\left(\mathrm{V}_{\mathrm{oc}}, 0\right)$ :

$0=I_{p h}-I_{o}\left[\exp \left(\frac{q V_{o c}}{N_{S} A k_{B} T}\right)-1\right]$

Maximum power point $\left(\mathrm{V}_{\mathrm{m}}, \mathrm{I}_{\mathrm{m}}\right)$ :

$I_{m}=I_{p h}-I_{o}\left[\exp \left(\frac{q\left(V_{m}+I_{m} R_{s}\right)}{N_{s} A k_{B} T}\right)-1\right]$ 


\section{3 . BOUNDARIES IDENTIFICATION METHODS}

Three distinct strategies had been performed to assess the four boundaries of sunlight-based modules (Iph, Io, A, and Rs). The first is the rearranged express technique, which depends on a totally improved numerical arrangement. The subsequent one is the incline strategy that relies upon the piece of its calculation on a math estimation, and the third technique is iterative, which is situated in a piece of its calculation on a mathematical goal.

\subsection{Simplified explicit method}

This method considers the following assumptions (Eckstein, 1990):

$$
I_{p h}=I_{s c}
$$

From that, Eq. (1) and (4) can be summarized as the following:

$$
\begin{aligned}
& I=I_{s c}\left[1-\exp \left(-\frac{q\left(V-V_{o c}+I R_{s}\right.}{N_{s} A k_{B} T}\right)\right] \\
& I_{m}=I_{s c}\left[1-\exp \left(\frac{q\left(V_{m+} I_{m} R_{s}\right.}{N_{s} A k_{B} T}\right)\right]
\end{aligned}
$$

Then, the series resistance can be obtained in Equation 8:

$$
R_{S}=\frac{\frac{N_{s} A k_{B}}{q} \ln \left(1-\frac{I_{m}}{I_{s c}}\right)+V_{o c}-V_{m}}{I_{m}}
$$

The ideality factor A can be found from the fact that the derivative of the maximum power equals zero, which expressed in Eq. (9):

$$
A=\frac{q}{N_{s} k_{B} T_{c}} \cdot \frac{2 V_{m}-V_{o c}}{\left[\frac{I_{m}}{I_{s c}-I_{m}}+\ln \left(1-\frac{I_{m}}{I_{s c}}\right)\right]}
$$

\subsection{Slope method}

The series resistance influence remarkably with the I-V characteristic curve slope in the proximity of the point $\left(\mathrm{V}_{\mathrm{oc}}, 0\right)$, which is the significant difference between the present and simplified methods in the series resistance calculating manner (Walker, 2001).

Therefore, the following equation can be used to calculate $\mathrm{R}_{\mathrm{s}}$ :

$$
R_{S}=-\frac{d V}{d I_{a t V o c}}-\frac{1}{\frac{I_{o} q}{N_{S} k_{B} T_{c}} \exp \left(\frac{q V_{o c}}{N_{s} A k_{B} T}\right)}
$$


The slope at the point $\left(\mathrm{V}_{\mathrm{oc}}, 0\right)$ is deduced geometrically from manufacturer data, as shown in Fig. (2).

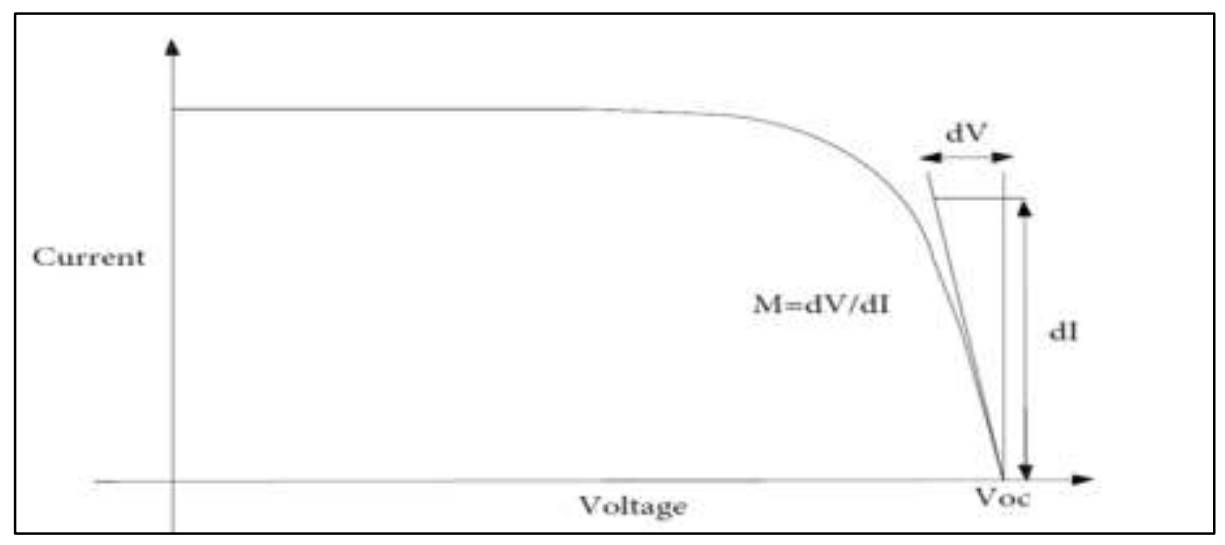

Figure 2. The slope at the open-circuit voltage region at the I-V curve.

\subsection{Iterative method}

The contrast between the iterative strategy and the two past techniques lies in arrangement opposition ascertaining structure. The temperature coefficient of the open-circuit voltage can be gotten tentatively, which is used to give an extra condition to compute the arrangement obstruction. In this current strategy, the arrangement obstruction esteem is determined by utilizing an iterative technique in the $\operatorname{span}[0, \mathrm{Rs}, \max ]$, where $\max$ is the greatest conceivable estimation of arrangement opposition (Celik and Acikgoz, 2007), where the value of A approaches to 1, therefore, $\mathrm{R}_{\text {s.max }}$ can be determined by Equation 11 :

$R_{s \max }=\frac{\frac{N_{s} k_{B} T}{q} \ln \left(1-\frac{I_{m}}{I_{s c}}\right)+V_{o c}-V_{m}}{I_{m}}$

By the same equations, Eq. (5), Eq. (7), and Eq. (9) in section 3.1 of the first method, the other three parameters $\left(\left(\mathrm{I}_{\mathrm{ph}}, \mathrm{I}_{\mathrm{o}}\right.\right.$, and $\left.\mathrm{A}\right)$ can be calculated. Many authors studied the solar radiation and temperature change effect on the PV module power output wares, the linear relationship of the short circuit current with the solar irradiance, while a logarithmic relationship of the open-circuit voltage with solar irradiance. As well, the manufacturers provided temperature coefficients by experimental evaluation used to predict the reduction of various PV solar module output parameters with temperature rise as in the following formulas:

$I_{s c}=I_{s c \text { ref }} \frac{G}{G_{r e f}}+\mu_{s c}\left(T-T_{r e f}\right)$

$V_{o c}=V_{o c \text { ref }}+V_{T} \ln \left(\frac{G}{G_{\text {ref }}}\right)+\mu_{o c}\left(T-T_{\text {ref }}\right)$

The variation of the ideality factor with temperature is given by Eq. (14) (Villalva, et al., 2009):

$\frac{A}{A_{\text {ref }}}=\frac{T}{T_{\text {ref }}}$ 


\section{RELATIVE ERROR AS MEASURE OF ACCURACY}

It is used to measure precision which is the proportion of the outright blunder of estimation to the estimation being taken. As such, this kind of mistake is comparative with the size of the thing being estimated. It is communicated as a rate and has no units as communicated in condition (15).

$\mathrm{RE}=\frac{V A-V E}{V E} * 100 \%$

$\mathrm{VA}=$ Measured maximum power output

$\mathrm{VE}=$ Theoretical maximum power output

\section{EXPERIMENTAL WORK}

The experimental work was performed for the examination of two solar PV modules: monocrystalline silicon, copper indium gallium di-selenide that present in Fig. (3). The manufacturers provide lists of the modules' specifications at reference conditions STC $\left(1000 \mathrm{~W} / \mathrm{m}^{2}\right.$ and $25^{\circ} \mathrm{C}$ ). The solar modules were calibrated according to a standard procedure available and tested under the outdoor exposure in Baghdad city located at a latitude of $33.33^{\circ} \mathrm{N}$ and longitude of $44.43^{\circ} \mathrm{E}$. The experimental measurements were done at the Energy Laboratory of Energy Engineering Department / University of Baghdad period started from 1 January to the end of June 2020.

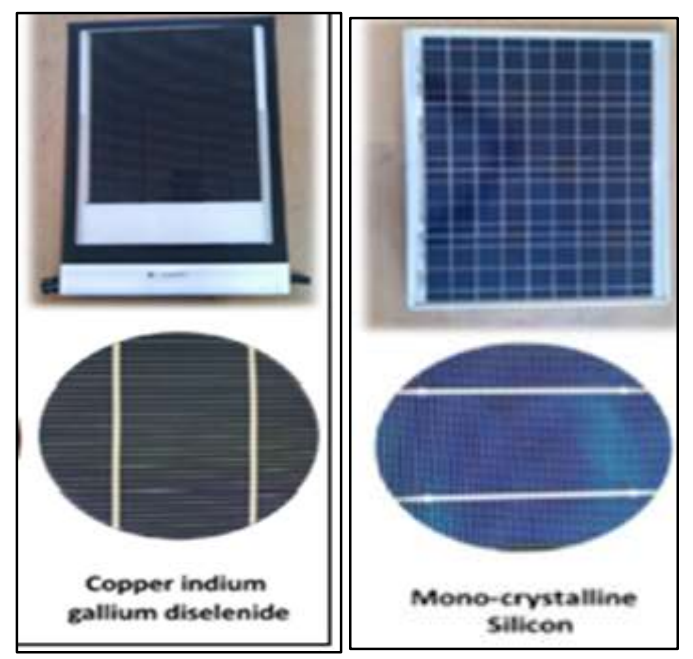

Figure 3. The two PV modules used in the test.

A movable steel structure (attached with wheels) was designed to support the PV modules and tilted with $33^{\circ}$ (local latitude of Baghdad city) above the ground horizon, as shown in Fig. (4). 


\section{Number $4 \quad$ Volume 27 April $2021 \quad$ Journal of Engineering}

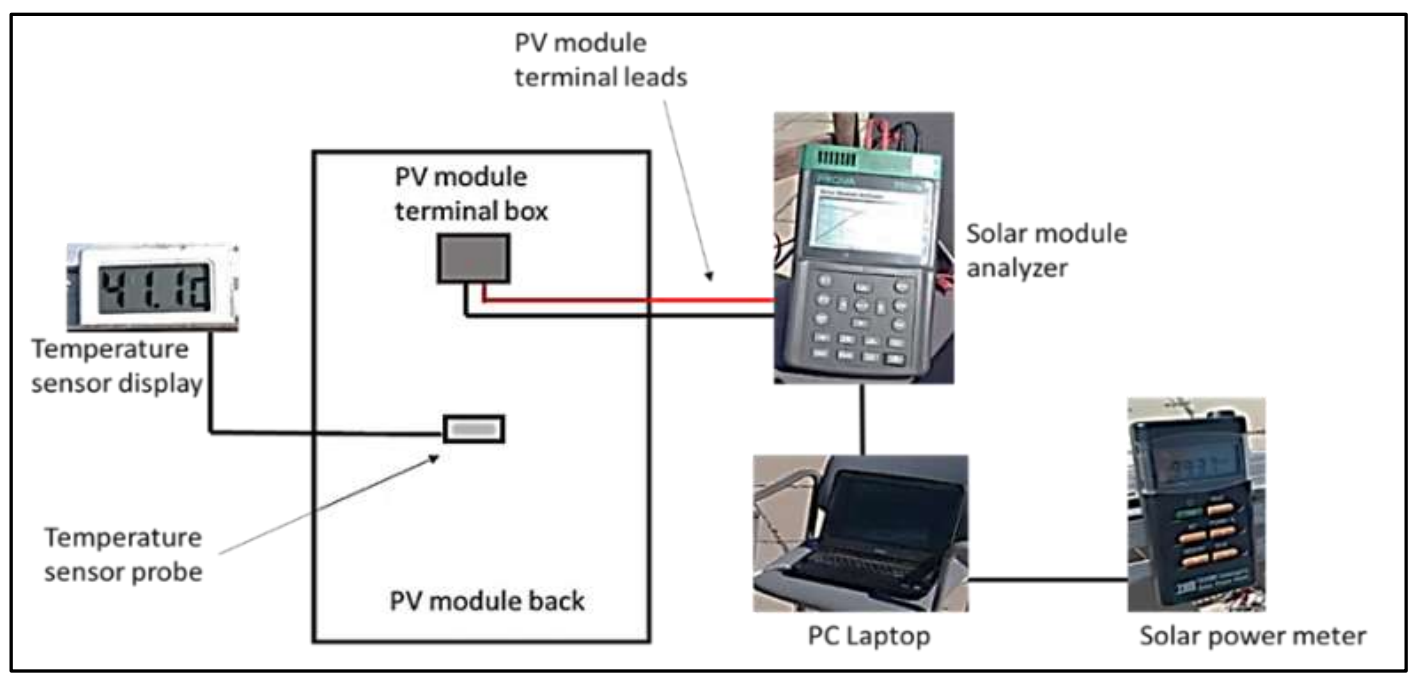

Figure 4. Experiment setup.

The holding frame was attached with casters (wheels) to be moved and rotated easily. The solar power meter device was hanged up and fixed on the structure frame perpendicularly to the plane of the module A laptop computer was connected to the PROVA 200A to transfer the data directly as an Excel spreadsheet. The time at which the tests were done was mostly from 9:00 AM to 2:00 PM in randomly selected days in five months from 1 January to the end of June 2020.

To extract solar modules parameters, temperature must be fixed within temperature range 20$25 \mathrm{oC}$, and solar radiation must be kept constant at a certain level despite sticking to one level restricts and limits the experimental data because of time issue weather instability. Therefore, in order to cover as much as possible, the temperature range is seeking more accuracy. The measurements were conducted for two solar radiation levels $\left(600\right.$ and $\left.1000 \mathrm{~W} / \mathrm{m}^{2}\right)$ and fixed solar module temperature within $20-25^{\circ} \mathrm{C}$. This was done in two steps. For the first three months (January, February, and March) of work (winter season in Iraq), a score for the solar panel temperature between $20-25^{\circ} \mathrm{C}$ was got and with the help of work timing from 9 AM to 2 PM. For the second step, for the last three months (April, May, and June) of work, a score for the solar panel temperature at $25^{\circ} \mathrm{C}$ was got through using air-condition external energy laboratory, which contains a glass window for entering the sun's rays, and that is the temperature of the solar panel was controlled to be $25^{\circ} \mathrm{C}$.

The modules were cleaned from any dust or dirt before the measurements. Each measurement was achieved at as constant solar radiation as possible. The holding frame was manually rotated to follow the sun and keep the incident radiation within the specified range. The temperatures were recorded from the module's backside, and Solar Module Analyzer had accomplished IV scanning process. For more accuracy, the previous steps repeated more than one time for a specific temperature, especially for a partly cloudy day. 


\section{RESULTS AND DISCUSSION}

This work summarizes the findings and contributions made by MATLAB code used for the calculation process for the two PV solar modules technologies characteristics at STC $(\mathrm{G}=600$ $\mathrm{W} / \mathrm{m}^{2}$ and $\left.\mathrm{T}=25^{\circ} \mathrm{C}\right)$ and at $\left(\mathrm{G}=1000 \mathrm{~W} / \mathrm{m}^{2}\right.$ and $\left.25^{\circ} \mathrm{C}\right)$ for monocrystalline silicon and copper indium gallium di-selenide. The solar radiation was measured in the Energy Laboratory. It contains a large window that transmits solar radiation, and the air temperature was controlled by central cooling, and thus conditions became almost standard. Three solar module parameter extracting methods, simplified explicit, slope, and iterative methods, were applied to find the PV solar module parameters.

Fig. (5) and Fig. (6) show the calculated values of IV and PV data using the three methods with the corresponding experimental measurement ones of copper indium gallium di-selenide PV solar module at solar radiation flux, $600 \mathrm{~W} / \mathrm{m}^{2}$, and $1000 \mathrm{~W} / \mathrm{m}^{2}$. Furthermore, it is easy to achieve this solar radiation because Iraq's climate conditions enjoy a high solar radiation domain (Ahmad et al., 1983). The average maximum calculated power outputs are $4.9 \mathrm{~W}, 4.3 \mathrm{~W}$, and $5.8 \mathrm{~W}$ for slope, simplified and iterative methods, respectively, at $1000 \mathrm{~W} / \mathrm{m}^{2}$ solar irradiance, while the average maximum measured power value is $5 \mathrm{~W}$. On the other hand, the average maximum calculated power outputs are $2.52 \mathrm{~W}, 1.8 \mathrm{~W}$, and $3.8 \mathrm{~W}$ for slop, simplified and iterative methods, for the methods when the solar irradiance $600 \mathrm{~W} / \mathrm{m}^{2}$, the average maximum measured power value is 2.6 W.

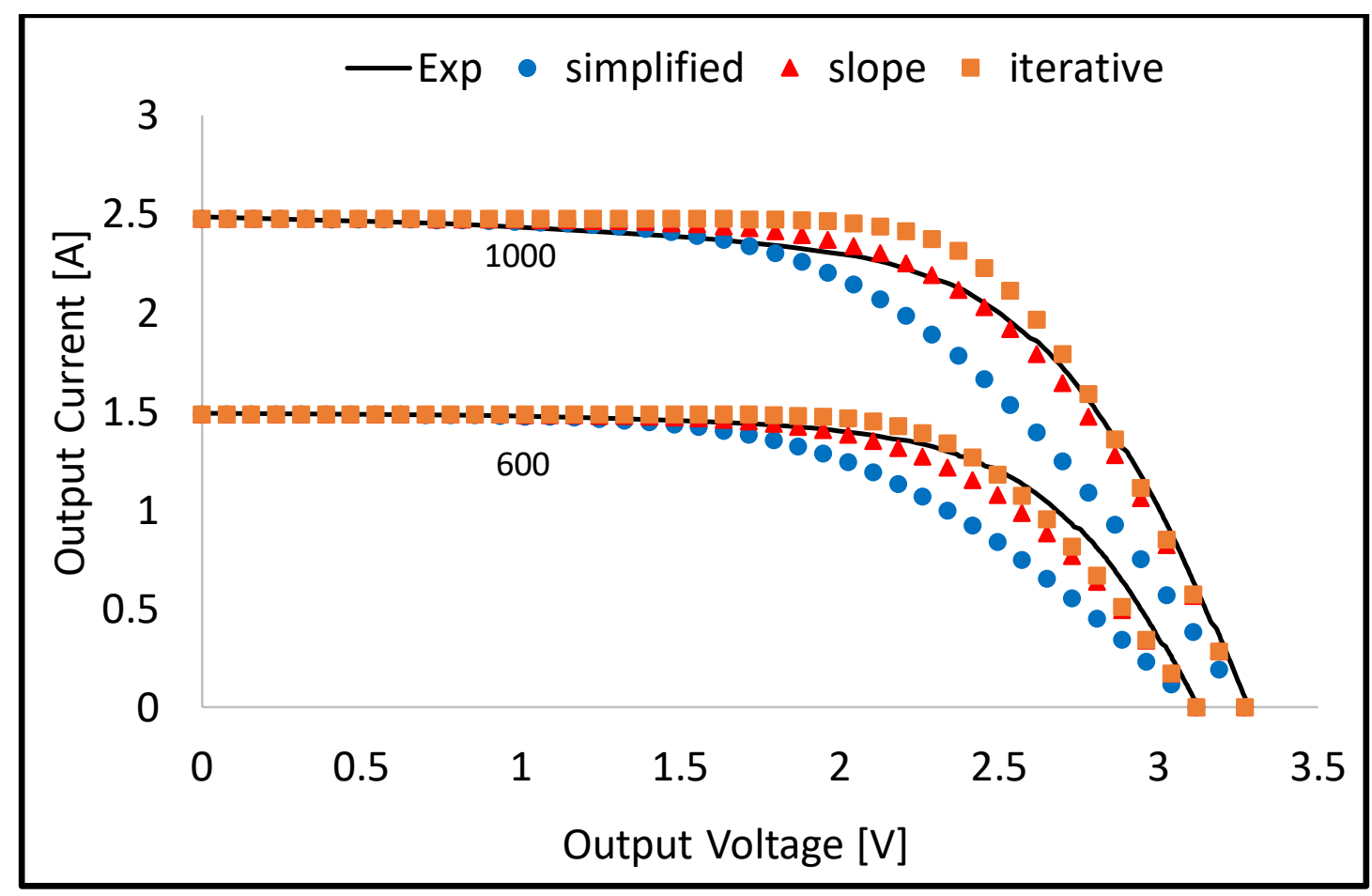

Figure 5. I-V characteristic curves of copper indium gallium di-selenide PV solar module with $\left(\mathrm{G}=600 \mathrm{~W} / \mathrm{m}^{2}\right.$ and $\left.1000 \mathrm{~W} / \mathrm{m}^{2}, \mathrm{~T}=25^{\circ} \mathrm{C}\right)$ using different methods. 


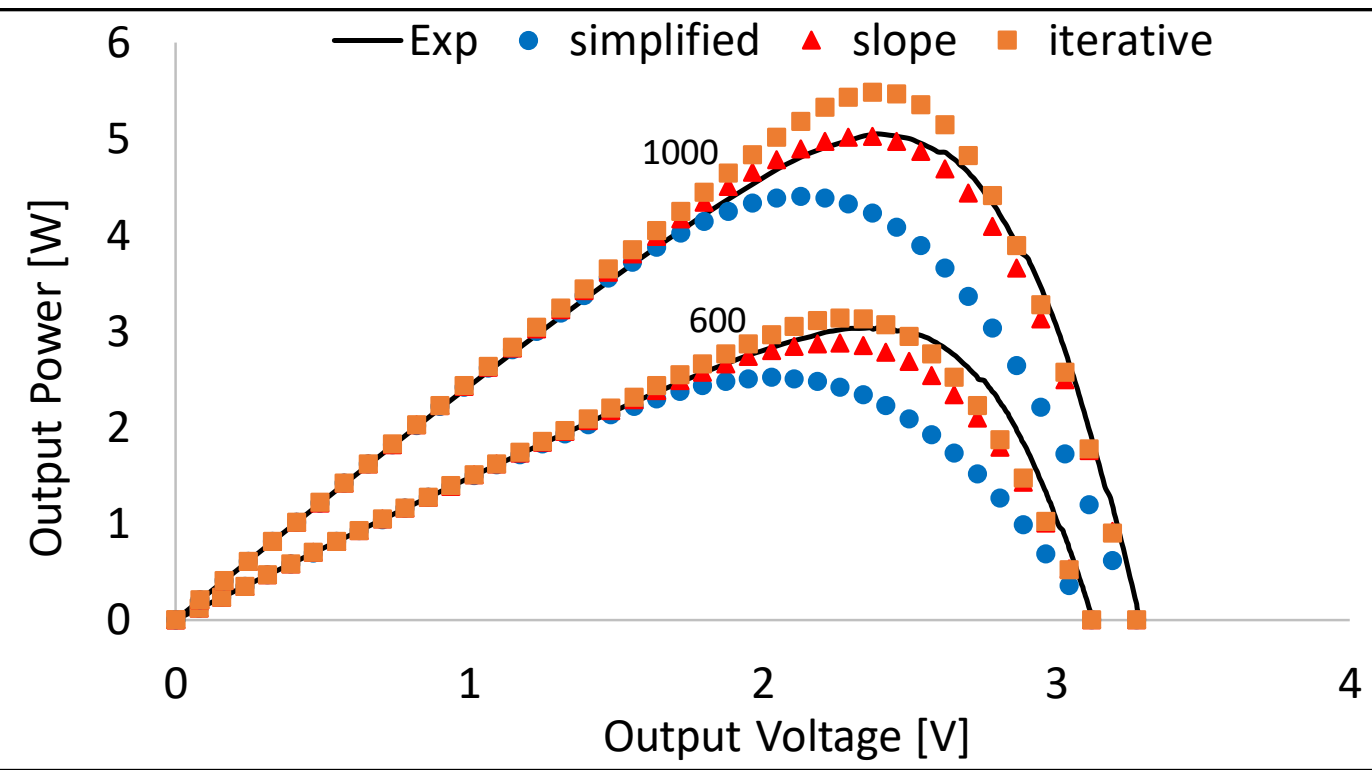

Figure 6. P-V characteristic curves of copper indium gallium di-selenide PV solar modules with $\left(\mathrm{G}=600 \mathrm{~W} / \mathrm{m}^{2}\right.$ and $\left.1000 \mathrm{~W} / \mathrm{m}^{2}, \mathrm{~T}=25^{\circ} \mathrm{C}\right)$ by using different extracting methods.

Fig. (7) and Fig. (8) show the resulted IV and PV curves for monocrystalline silicon PV solar modules with $1000 \mathrm{~W} / \mathrm{m}^{2}$ and $600 \mathrm{~W} / \mathrm{m}^{2}$. The average maximum power output calculated had different values of $26.8 \mathrm{~W}, 26 \mathrm{~W}$, and $28 \mathrm{~W}$ for slope, simplified and iterative methods, respectively, with solar irradiance $1000 \mathrm{~W} / \mathrm{m}^{2}$. In contrast, the average maximum measured power value is $27 \mathrm{~W}$. The power output values recorded magnitudes of $15 \mathrm{~W}, 13 \mathrm{~W}$, and $16 \mathrm{~W}$, respectively, for the solar irradiance $600 \mathrm{~W} / \mathrm{m}^{2}$ and the average maximum measured value is 14.65 W.

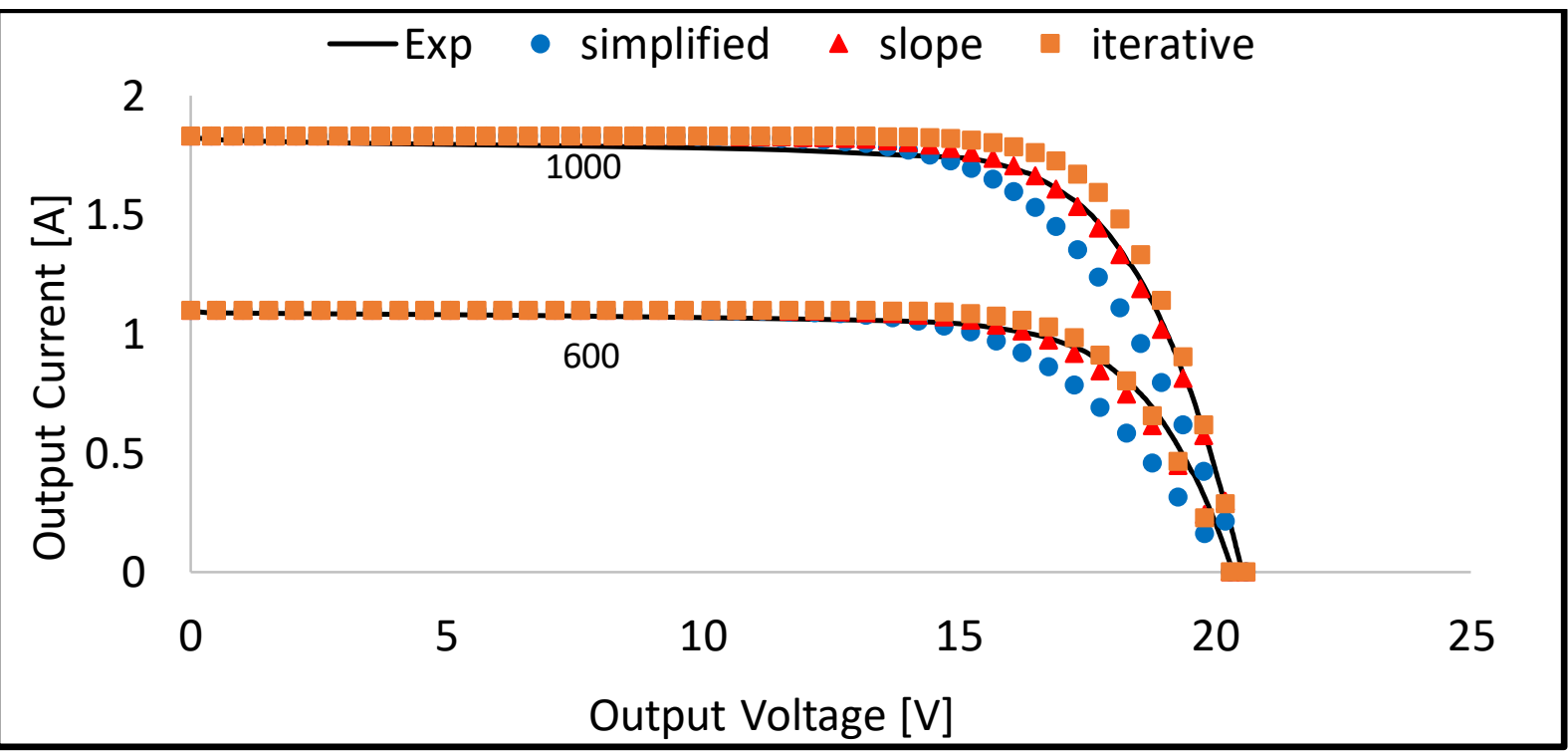

Figure 7. I-V characteristic curves of mono-crystalline silicon PV solar module with $(\mathrm{G}=600$ $\mathrm{W} / \mathrm{m}^{2}$ and $1000 \mathrm{~W} / \mathrm{m}^{2}, \mathrm{~T}=25^{\circ} \mathrm{C}$ ) using different methods. 


\section{$\begin{array}{lllll}\text { Number } 4 & \text { Volume } 27 & \text { April } 2021 & \text { Journal of Engineering }\end{array}$}

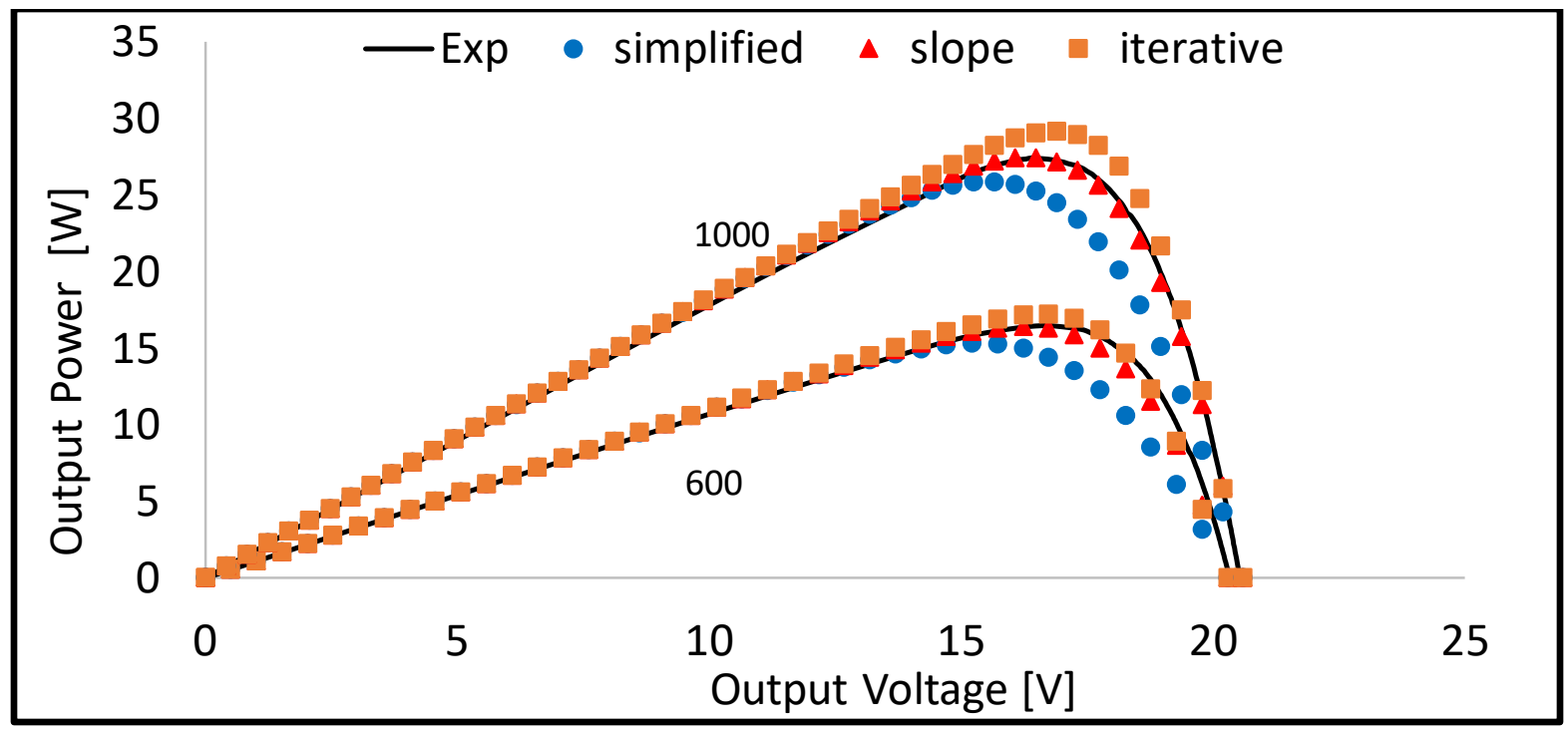

Figure 8. P-V characteristic curves of mono-crystalline silicon PV solar module with $(\mathrm{G}=600$ $\mathrm{W} / \mathrm{m}^{2}$ and $1000 \mathrm{~W} / \mathrm{m}^{2}, \mathrm{~T}=25^{\circ} \mathrm{C}$ ) using different methods.

The PV module boundaries assessment characterizing and estimating its trademark bends (I-V and $\mathrm{P}-\mathrm{V}$ bends) has been accomplished. Three unique strategies for PV module boundaries separating have been inspected, and the estimations of the boundaries were utilized to mimic the currentvoltage and force voltage qualities of the module, thusly, the general blunders rate have been ascertaining utilizing condition 15 , which was examined already in area 3.4 ,

The maximum power errors at (600 and 1000)W/m2 for both current-voltage and power-voltage values with the corresponding measured ones using the slope method are $0.5 \%$ and $3 \%$ for monocrystalline silicon and copper indium gallium di-selenide, respectively. For the iterative method, $5 \%$ and 10\% for monocrystalline silicon and copper indium gallium di-selenide, respectively. Finally, for the simplified explicit $8 \%$ and $9 \%$, for monocrystalline silicon and copper indium gallium di-selenide, respectively.

The maximum power output predictions of the incline strategy were so near estimated values as contrasted and the other two techniques due to the slant strategy situated in a piece of its calculation on a mathematical figuring, the unequivocal technique dependent on a scientific arrangement, and the iterative strategy dependent on a mathematical goal.

The experimental measurements have been done to investigate the applicability of three methods. Consequently, new tests have been done on the four different PV solar modules at $600 \mathrm{~W} / \mathrm{m}^{2}$ and $1000 \mathrm{~W} / \mathrm{m}^{2}$, the obtained results are tabled in the Tables (from 1 to 4 ) that represent the several parameters values for the previously maintained PV solar modules technologies. Significance agreements between the results obtained of the simplified explicit method and slope method that are diverged from the iterative method. 


\section{$\begin{array}{lllll}\text { Number } 4 & \text { Volume } 27 & \text { April } 2021 & \text { Journal of Engineering }\end{array}$}

Table 1. Four unknown parameters value at $\left(\mathrm{G}=600 \mathrm{~W} / \mathrm{m}^{2}, \mathrm{~T}=25^{\circ} \mathrm{C}\right)$ for mono-crystalline silicon.

\begin{tabular}{|c|c|c|c|}
\hline & Simplified explicit method & Slope Method & Iterative Method \\
\hline Voc & 19.351208 & 19.351208 & 19.351208 \\
\hline Isc & 1.104155536 & 1.104155536 & 1.104155536 \\
\hline Vm & 15.331208 & 15.331208 & 15.331208 \\
\hline Im & 1.008998488 & 1.008998488 & 1.008998488 \\
\hline A & 1.270717746 & 1.270717746 & 0.975760387 \\
\hline Iph & 1.104155536 & 1.104155536 & 1.110924169 \\
\hline Io & $1.85355 \mathrm{E}-07$ & $1.85355 \mathrm{E}-07$ & $3.7371 \mathrm{E}-09$ \\
\hline Rs & 1.615548906 & 0.783827356 & 1.25 \\
\hline
\end{tabular}

Table 2. Four unknown parameters value at $\left(\mathrm{G}=1000 \mathrm{~W} / \mathrm{m}^{2}, \mathrm{~T}=25^{\circ} \mathrm{C}\right)$ for mono-crystalline silicon.

\begin{tabular}{|c|c|c|c|}
\hline & Simplified explicit method & Slope Method & Iterative Method \\
\hline Voc & 19.661208 & 19.661208 & 19.661208 \\
\hline Isc & 1.838659547 & 1.838659547 & 1.838659547 \\
\hline Vm & 15.581208 & 15.581208 & 15.581208 \\
\hline Im & 1.679962707 & 1.679962707 & 1.679962707 \\
\hline A & 1.294166467 & 1.294166467 & 0.982155498 \\
\hline Iph & 1.838659547 & 1.838659547 & 1.842767834 \\
\hline Io & $3.18748 \mathrm{E}-07$ & $3.18748 \mathrm{E}-07$ & $5.12246 \mathrm{E}-09$ \\
\hline Rs & 1.006836822 & 0.619645733 & 0.77 \\
\hline
\end{tabular}

Table 3. Four unknown parameters value $\left(\mathrm{G}=600 \mathrm{~W} / \mathrm{m}^{2}, \mathrm{~T}=25^{\circ} \mathrm{C}\right)$ for copper indium gallium di-selenide.

\begin{tabular}{|c|c|c|c|}
\hline & Simplified explicit method & Slope Method & Iterative Method \\
\hline Voc & 3.065276 & 3.065276 & 3.065276 \\
\hline Isc & 1.498697467 & 1.498697467 & 1.498697467 \\
\hline Vm & 1.959276 & 1.959276 & 1.959276 \\
\hline Im & 1.27826028 & 1.27826028 & 1.27826028 \\
\hline $\mathrm{A}$ & 1.081037033 & 1.081037033 & 0.958598473 \\
\hline
\end{tabular}


Number $4 \quad$ Volume 27 April $2021 \quad$ Journal of Engineering

\begin{tabular}{|c|c|c|c|}
\hline Iph & 1.498697467 & 1.498697467 & 1.551009567 \\
\hline Io & $8.02511 \mathrm{E}-08$ & $8.02511 \mathrm{E}-08$ & $9.67093 \mathrm{E}-09$ \\
\hline Rs & 0.621641837 & 0.240260713 & 0.580633918 \\
\hline
\end{tabular}

Table 4. Four unknown parameters value $\left(\mathrm{G}=1000 \mathrm{~W} / \mathrm{m}^{2}, \mathrm{~T}=25^{\circ} \mathrm{C}\right)$ for copper indium gallium di-selenide.

\begin{tabular}{|c|c|c|c|}
\hline & Simplified explicit method & Slope Method & Iterative Method \\
\hline Voc & 3.114276 & 3.114276 & 3.114276 \\
\hline Isc & 2.492753933 & 2.492753933 & 2.492753933 \\
\hline Vm & 2.217276 & 2.217276 & 2.217276 \\
\hline Im & 2.1234594 & 2.1234594 & 2.1234594 \\
\hline A & 1.684065621 & 1.684065621 & 0.96389237 \\
\hline Iph & 2.492753933 & 2.492753933 & 2.49930386 \\
\hline Io & $3.05434 \mathrm{E}-05$ & $3.05434 \mathrm{E}-05$ & $1.24995 \mathrm{E}-08$ \\
\hline Rs & 0.276308165 & 0.165095818 & 0.231559298 \\
\hline
\end{tabular}

These results will certainly depend on each method's assumption and how these assumptions may deviate from the calculated values than the measured ones. For example, the Simplified Explicit Method assumes that Iph=Isc, Eq. (5) uses this assumption to find the module model parameters. Furthermore, the ideality factor A can be found because the maximum power derivative is equal to zero, which is expressed as follows.

The Slope Method is based on the fact that the series resistance influences remarkably the slope of the characteristic curve IV in the vicinity of the point (Voc, 0). In the Iterative Method, the series resistance can be calculated using the experimental value of the open-circuit voltage obtained experimentally. In this method, the series resistance value is calculated by using the iterative method in the interval $\left[0, \mathrm{R}_{\mathrm{s}, \max }\right]$. The manufacturers also provided temperature coefficients based on the experimental evaluation that was used to predict the reduction of various PV solar module output parameters with temperature rise.

On the other hand, several researchers investigated PV parameters using experimental and modelling as (Khezzar, et al., 2009) who reported three methods of a slope, alterative and simplified explicit to investigate the four parameters and to simulate the current-voltage and power-voltage characteristics, however, they found the slope method is the most accurate one.

Furthermore, (Et-Torabi, et al., 2017), reported a comparable two-parameter study methods appreciation: the analytical method applied on the double diode model and the iterative method called Gauss-Seidel applied on the single diode model. These parameter estimation methods were based on the manufacturer's datasheets of various PV technologies. The results suggested that the analytical method could be very beneficial for monocrystalline and multi-crystalline modules 


\section{Number $4 \quad$ Volume 27 April $2021 \quad$ Journal of Engineering}

technologies, respectively. Still, the iterative method is the most suitable for the thin-film module technology.

Yet, (Kler, et al., 2019) explored a novel mixture analyzer, hybridized inside inquiry calculation (HISA) to gauge the PV sun oriented module/cell boundaries.

The assessment has been finished utilizing twofold and single diode-base models of PV cell/module that their separate IV nonlinear trademark utilizes exploratory information from five contextual analyses containing two cells and three modules using multi-glasslike, monotranslucent, and slight film-based PV innovation. The acquired end from the proposed HISA was suggested as a promising enhancement method for PV cell/module boundaries assessment.

\section{CONCLUSIONS}

To assess the PV module boundaries characterizing and estimating its trademark bends (IV and PV bend) are accomplished. Three distinct techniques to removing four boundaries of PV modules have been inspected. The estimations of the boundaries were utilized to reproduce the currentvoltage and force voltage attributes of the module. The three techniques were an unequivocally improved strategy dependent on a logical arrangement, a slant strategy dependent on the piece of trial information, and an iterative technique dependent on a mathematical goal. The percentage maximum power errors at $(600$ and 1000$) \mathrm{W} / \mathrm{m}^{2}$ for both current-voltage and power-voltage values with the corresponding measured ones using the slope method are $0.5 \%$ and $3 \%$ for monocrystalline silicon copper indium gallium di-selenide, respectively. For the iterative method, $5 \%$ and $10 \%$ for monocrystalline silicon and copper indium gallium di-selenide, respectively. Finally, for the simplified explicit $8 \%$ and $9 \%$, for monocrystalline silicon and copper indium gallium di-selenide consequence, the slope method is the accurate one, which is less influenced by the meteorological conditions. Yet, following the above-calculated percentage maximum power errors, it was concluded that the slope method gives more close results with the corresponding measured values than the other two methods for the two PV solar modules that have been used.

\section{REFERENCES}

- Ahmad, I., Al-Hamadani, N., and Ibrahim, K., 1983. Solar radiation maps for Iraq. Solar Energy, 31(1), pp.29-44.

- Ahmad, T., Sobhan, S., and Nayan, M.F., 2016. Comparative analysis between single diode and double diode model of PV cell: concentrate different parameters effect on its efficiency. Journal of Power and Energy Engineering, 4(3), pp.31-46.

- Ali, M.H., Rabhi, A., Haddad, S., and El Hajjaji, A., 2017. Real-Time Determination of Solar Cell Parameters. Journal of Electronic Materials, 46(11), pp.6535-6543.

- Catelani, M., Ciani, L., Kazimierczuk, M.K., and Reatti, A., 2016. Matlab PV solar concentrator performance prediction based on triple junction solar cell model. Measurement, 88, pp.310-317. 


\section{Number $4 \quad$ Volume 27 April $2021 \quad$ Journal of Engineering}

- Cattin, J., Dupré, O., Aïssa, B., Haschke, J., Ballif, C., and Boccard, M., 2019. Optimized Design of Silicon Heterojunction Solar Cells for Field Operating Conditions. IEEE Journal of Photovoltaics, 9(6), pp.1541-1547.

- Chaibi, Y., Allouhi, A., Malvoni, M., Salhi, M., and Saadani, R., 2019. Solar irradiance and temperature influence on the photovoltaic cell equivalent-circuit models. Solar Energy, 188, pp.1102-1110.

- Chen, H., Jiao, S., Wang, M., Heidari, A.A., and Zhao, X., 2020. Parameters identification of photovoltaic cells and modules using diversification-enriched Harris hawks optimization with chaotic drifts. Journal of Cleaner Production, 244, p.118778.

- Ebrahimi, S.M., Salahshour, E., Malekzadeh, M., and Gordillo, F., 2019. Parameters identification of PV solar cells and modules using flexible particle swarm optimization algorithm. Energy, 179, pp.358-372.

- Eckstein, J.H., 1990. Detailed modeling of photovoltaic components. Solar Energy Laboratory, University of Wisconsin, Madison.

- Hashim, Emad T., and Akram A. Abbood., 2016. Temperature Effect on Power Drop of Different Photovoltaic Module, Journal of Engineering 22(5):126-43.

- Hahsim, Emad Talib., 2016. Determination of Mono-Crystalline Silicon Photovoltaic Module Parameters Using Three Different Methods, Journal of Engineering 22(7):92-107.

- Hashim, E.T., Kasim, NK., and Obaid, NM., 2019. Performance Assessment of First Gridtied PV Solar System under Baghdad City Climate Condition. Iraqi Journal of Science and Technology, 10(1), pp.63-71.

- Khezzar, R., Zereg, M., and Khezzar, A., 2009, November. Comparative study of mathematical methods for parameters calculation of current-voltage characteristic of photovoltaic module. In 2009 International Conference on Electrical and Electronics Engineering-ELECO 2009 (pp. I-24). IEEE.

- Kler, D., Goswami, Y., Rana, K.P.S., and Kumar, V., 2019. A novel approach to parameter estimation of photovoltaic systems using hybridized optimizer. Energy Conversion and Management, 187, pp.486-511.

- Kumar, N.M., Sudhakar, K., and Samykano, M., 2020. Performance evaluation of CdTe BIPV roof and façades in tropical weather conditions. Energy Sources, Part A: Recovery, Utilization, and Environmental Effects, 42(9), pp.1057-1071.

- Mathew, M., and Hossain, J., 2017, December. Analysis of a grid connected solar photovoltaic system with different PV technologies. In 2017 IEEE International Conference on Circuits and Systems (ICCS) (pp. 264-269). IEEE. 
- Munji M. K., W. Okullo, E. E. Van Dyk, and F. J. Vorster, 2010. Local device parameter extraction of a concentrator photovoltaic cell under solar spot illumination, Solar Energy Materials and Solar Cells, vol. 94, no. 12, pp. 2129-2136, Dec.

- Necaibia, A., Bouraiou, A., Ziane, A., Sahouane, N., Hassani, S., Mostefaoui, M., Dabou, R., and Mouhadjer, S., 2018. Analytical assessment of the outdoor performance and efficiency of grid-tied photovoltaic system under hot dry climate in the south of Algeria. Energy Conversion and Management, 171, pp.778-786.

- Obaid, N.M., Hashim, E.T., and Kasim, NK., 2020. Performance Analyses of 15 kW GridTied Photo Voltaic Solar System Type under Baghdad city climate. Journal of Engineering, 26(4), pp.21-32.

- Subudhi B., and R. Pradhan, 2011. Characteristics Evaluation and Parameter Extraction of a Solar Array Based on Experimental Analysis, IEEE international conference on Power Electronics and Drive System (PEDS), December, pp. 340-344.

- Villalva, M.G., Gazoli, J.R., and Ruppert Filho, E., 2009. Comprehensive approach to modeling and simulation of photovoltaic arrays. IEEE Transactions on power electronics, 24(5), pp.1198-1208.

- Walker, G., 2001. Evaluating MPPT converter topologies using a MATLAB PV model. Journal of Electrical \& Electronics Engineering, 21(1), pp.49-56.

- Wolf M., G. Noel, and R. Stirn, 1977. Investigation of the double exponential in the current-voltage characteristics of silicon solar cells, IEEE Transactions on Electron Devices, vol. 24, no. 4, pp. 419 - 428, April.

- Yu, K., Liang, J.J., Qu, B.Y., Chen, X., and Wang, H., 2017. Parameters identification of photovoltaic models using an improved JAYA optimization algorithm. Energy Conversion and Management, 150, pp.742-75. 
NOMENCLATURE

$\begin{array}{ll}\mathrm{A} & \begin{array}{l}\text { diode ideality factor } \\ \text { solar radiation, W/m }\end{array} \\ \mathrm{G} & \begin{array}{l}\text { output current of photovoltaic module, } \mathrm{A} \\ \text { short circuit Current, } \mathrm{A} \\ \mathrm{I}\end{array} \\ \mathrm{I}_{\mathrm{sc}} & \text { photo-generated current, } \mathrm{A} \\ \mathrm{I}_{\mathrm{ph}} & \text { current at maximum power point, } \mathrm{A} \\ \mathrm{I}_{\mathrm{m}} & \text { reverse Saturation current, } \mathrm{A} \\ \mathrm{I}_{\mathrm{o}} & \text { Boltzmann constant }\left(1.38 \mathrm{e}^{-23}\right) \\ \mathrm{k}_{\mathrm{B}} & \text { number of cells connected in series. } \\ \mathrm{N}_{\mathrm{s}} & \text { maximum power output, W } \\ \mathrm{P}_{\mathrm{m}} & \text { Charge of electron, } 1.6 \mathrm{e}^{-19} \mathrm{C} \\ \mathrm{q} & \text { series resistance, } \Omega \\ \mathrm{R}_{\mathrm{s}} & \text { open circuit Voltage, } \mathrm{V} \\ \mathrm{V}_{\mathrm{oc}} & \text { voltage at maximum power point, } \mathrm{V} \\ \mathrm{V}_{\mathrm{m}} & \end{array}$

